\author{
BARBARA MITRENGA \\ Wydział Humanistyczny \\ Uniwersytet Śląski w Katowicach \\ ORCID: 0000-0001-9389-8152
}

\title{
Terminologia związana z ekspresywnością języka i leksyką ekspresywną w ujęciu historycznym. Prolegomena ${ }^{1}$
}

\section{Wstęp}

W artykule podjęto próbę przybliżenia najważniejszych dotychczasowych ustaleń polskich badaczy na temat ekspresywności języka i leksyki ekspresywnej. Opracowanie ma charakter historycznojęzykowy - przedmiotem opisu są wybrane współczesne i dawne prace sygnalizujące lub podejmujące zagadnienie ekspresywnego zróżnicowania polszczyzny. Przedmiotem naukowej refleksji są zagadnienia teoretyczne dotyczące ekspresywności języka i leksyki ekspresywnej opracowane na podstawie czterech dawnych gramatyk i podręczników języka polskiego. Ponadto w artykule omówiono wybrane terminy związane z ekspresywnością języka i leksyką ekspresywną funkcjonujące w polskich pracach językoznawczych z ostatniego półwiecza (m.in. ekspresywność, ekspresja, znak ekspresywny, ekspresywizm). Celem artykułu jest zatem przedstawienie w zarysie, jak kształtowała się w ciągu lat polska terminologia związana z ekspresywnością języka i leksyką ekspresywną w zróżnicowanych źródłach (zarówno w pracach o charakterze dydaktycznym, jak i w opracowaniach naukowych) ${ }^{2}$.

Inspiracją do podjęcia tematu ekspresywności języka w ujęciu diachronicznym jest monografia Artura Rejtera pt. „Leksyka ekspresywna w historii języka polskiego.

1 Artykuł jest zmodyfikowaną wersją referatu LXXVII Zjazdu Polskiego Towarzystwa Językoznawczego nt. „Terminologia językoznawcza. Różne tradycje, różne języki”, który odbył się 16-17 września 2019 r. w Częstochowie.

2 Zarówno w części poświęconej analizie gramatyk i podręczników, jak i we fragmencie, w którym zaprezentowano prace polskich językoznawców, konieczne było zastosowanie kryteriów ograniczających analizowane źródła oraz literaturę przedmiotu do wybranych pozycji. Kryteria te wraz z ich uzasadnieniem znajdują się w dalszej części artykułu. 
Kulturowo-komunikacyjne konteksty potoczności” (Rejter, 2006), poświęcona leksyce ekspresywnej na podstawie ekspresywnych apelatywnych nazw osób, w której zakończeniu autor konstatuje, że wiele zagadnień dotyczących ekspresywności leksyki pozostaje wciąż do opracowania (Rejter, 2006, s. 225). Stwierdzenie to stało się dla autorki zachętą do bliższego przyjrzenia się w niniejszym artykule terminologii związanej z ekspresywnością języka i leksyką ekspresywną z perspektywy historycznej, a jednocześnie podjęcia zakrojonych na szerszą skalę badań poświęconych ekspresywności i leksyce ekspresywnej w ramach pragmalingwistyki historycznej ${ }^{3}$.

Ekspresywność postrzegana jest jako jeden z najistotniejszych wyznaczników potoczności (obok m.in. interaktywności), dlatego jej badanie - w przyszłych pracach autorki - opierać się będzie na materiale językowym wyekscerpowanym z dawnych dramatów, które są w możliwie największym stopniu zbliżone do tekstów potocznych (tzw. speech-related text types, czyli tekstów zapisanej mowy) ${ }^{4}$. Celem tak sprofilowanych badań będzie próba wyjaśnienia procesu kształtowania się ekspresywizmów w polszczyźnie, w tym poszukiwanie odpowiedzi m.in. na pytania o przyczyny zaników i przyrostów, a także przeobrażeń w słownictwie ekspresywnym polszczyzny. Niniejszy artykuł ma zatem charakter rozważań wstępnych, które stanowią punkt wyjścia do dalszych pogłębionych studiów nad zasygnalizowanymi zagadnieniami.

\section{Ekspresywność języka i leksyka ekspresywna na podstawie wybranych dawnych gramatyk i podręczników języka polskiego}

Przegląd wybranych dzieł z okresu od XV w. do 1939 r., zebranych w internetowym kompendium edukacyjnym „Dawne ortografie, gramatyki i podręczniki języka polskiego", opracowanym po kierunkiem Wandy Decyk-Zięby ${ }^{5}$, pozwala na sformułowanie wstępnych uwag na temat rodzącej się przez wieki świadomości zróżnicowania polszczyzny pod względem ekspresywnym wśród autorów dawnych gramatyk ${ }^{6}$, a także kształtowania się polskiej terminologii dotyczącej ekspresywności języka i leksyki ekspresywnej. Spośród blisko 50 dzieł uwzględnionych we wspomnianym kompendium wybrano trzy podręczniki lub gramatyki języka polskiego oraz jeden podręcznik do nauki języka włoskiego, w których eksplicytnie bądź implicytnie autorzy podejmują zagadnienia będące przedmiotem zainteresowania w niniejszym opracowaniu.

3 O możliwościach i ograniczeniach badań pragmalingwistycznych w perspektywie diachronicznej zob. Mitrenga, Pastuch, Wąsińska, w druku.

4 Materiał językowy do badań zaczerpnięty zostanie z Korpusu dawnych polskich tekstów dramatycznych (1772-1939), który powstaje w Instytucie Językoznawstwa Uniwersytetu Śląskiego w Katowicach pod kierunkiem Magdaleny Pastuch przy współpracy z konsorcjum CLARIN-PL (Common Language Resources \& Technology Infrastructure).

${ }^{5}$ https://gramatyki.uw.edu.pl/ (dostęp sierpień/wrzesień 2019).

6 Twórcy kompendium „Dawne ortografie, gramatyki i podręczniki języka polskiego” wszystkie analizowane dzieła nazywają ogólnie ,gramatykami”. Zob. https://gramatyki.uw.edu.pl/information/genesis (dostęp sierpień/wrzesień 2019). W niniejszym artykule określenie ,gramatyka” również będzie odnosiło się do publikacji o zróżnicowanej formie (np. podręcznika do nauki języka włoskiego czy podręcznika z ćwiczeniami ze stylistyki i rytmiki polskiej). 
Zwrócono uwagę na opinie autorów tych prac na temat ekspresywności języka i leksyki ekspresywnej oraz na to, w jaki sposób (implicytnie czy eksplicytnie) oraz przy wykorzystaniu jakich terminów są one opisywane. W tym kontekście zanalizowano następujące prace: „Grammatica Polono-Italica abo sposob łacny nauczenia się włoskiego języka krotko, gruntownie, choćby też i bez dyrekcyjej nauczyciela ku pożytkowi Narodu Polskiego z rożnych przedniejszych grammatykow z pilnością wygotowany” Adama Styli (Kraków 1675) ${ }^{7}$; „O początku, dawności, odmianach i wydoskonaleniu języka polskiego” Stanisława Kleczewskiego (Lwów 1767); „Stylistykę i rytmikę polską” Kazimierza Wóycickiego (Warszawa 1917) oraz „Gramatykę polską”, cz. II „Słowotwórstwo” Jana Łosia (Lwów-Warszawa-Kraków 1925). Przy ich wyborze zastosowano następujące kryteria: a) podejmowanie zagadnień związanych z ekspresywnością języka i/lub leksyką ekspresywną; ; b) prace opublikowane w języku polskim; c) zróżnicowany czas powstania ${ }^{9}$. Dla przejrzystości wywodu dawne gramatyki zaprezentowano w układzie chronologicznym. Omówienie każdego dzieła poprzedzono śródtytułem, który sygnalizuje najważniejsze spostrzeżenia na temat danej pracy w kontekście analizowanych zagadnień.

\section{a. Zdrobnienia, zgrubienia, słowa obelżywe - o zróżnicowaniu znaczeniowym i ,ekspresywnym"10 wyrazów pochodnych}

„Grammatica Polono-Italica...” A. Styli to siedemnastowieczny podręcznik do nauki języka włoskiego napisany w całości po polsku. Kamila Wincewicz - autorka opracowania na temat tego dzieła zamieszczonego w wymienionym kompendium - uważa, że A. Stylę należy zaliczyć do pionierów polskiej myśli gramatycznej, gdyż szczegółowo wyłożył gramatykę języka włoskiego w języku polskim, korzystając z wypracowanej w XVI w. terminologii, wówczas, gdy panowało przekonanie, że językiem naukowym może być tylko łacina (Wincewicz). W tym kontekście cenna jest również opinia Haliny Wiśniewskiej: „Za nieuzasadnione należy uznać sądy o rzadkiej i ciężko rodzącej się

${ }^{7}$ Pełne dane bibliograficzne źródeł podano w zestawieniu na końcu artykułu.

${ }^{8}$ Jest to podstawowe kryterium, dzięki któremu zawężono pole obserwacji do prac, które podejmują zagadnienia istotne dla tematu niniejszego artykułu. Dzięki charakterystyce każdej gramatyki uwzględnionej w kompendium edukacyjnym „Dawne ortografie, gramatyki i podręczniki języka polskiego” możliwe było prześledzenie struktury i zawartości poszczególnych części czy rozdziałów gramatyk. Jeśli opis ten wskazywał na występowanie interesującej autorkę problematyki, sięgała ona bezpośrednio do zdygitalizowanych wersji dzieł udostępnionych w bibliotekach cyfrowych.

${ }^{9}$ Wybrano publikacje, które zgodnie z podziałem gramatyk w ujęciu Stanisława Urbańczyka należą zarówno do przednaukowego etapu rozwoju językoznawstwa polskiego (do 2. połowy XVIII w., tj. gramatyk Walentego Szylarskiego z 1770 r. oraz Onufrego Kopczyńskiego z lat 1778-1783), jak prace Adama Styli i Stanisława Kleczewskiego, jak i etapu naukowego (od 2. połowy XVIII w.), prace Kazimierza Wóycickiego i Jana Łosia. Analizowane gramatyki powstały w przedziale czasowym od XVII do XX w. Informację o podziale gramatyk zaczerpnięto ze strony kompendium: https://gramatyki.uw.edu.pl/history (Urbańczyk 1993; za: Decyk-Zięba online2).

${ }_{10}$ Zapis w cudzysłowie oznacza, że w analizowanych rozdziałach podręcznika Styli informacja o ekspresywnym zróżnicowaniu wyrazów pochodnych nie pojawia się w sposób eksplicytny. 
polskiej nomenklaturze naukowej, gdyż właśnie ten podręcznik pozwala wnioskować, że była ona w powszechnym obiegu" (Wiśniewska, 1994, s. 229, za: Wincewicz).

W podręczniku A. Styli, w rozdziale poświęconym częściom mowy, w trzech podrozdziałach poruszone zostały zagadnienia dotyczące zdrobnień, zgrubień i słów obelżywych. A. Styla wprowadza omówienie łacińskich terminów („De diminutivis”, s. 49-50, czyli o imionach, „które od inszych pochodzące ich znaczenie zmieniają”; „De augmentativis”, s. 50, tj. o imionach ,przyczynienie znaczących”, oraz „De vituperativis”, s. 50-51, czyli o imionach ,naganę lub wzgardę znaczących”). W kompendium czytamy: „W XVII wieku nie wyodrębniano jeszcze słowotwórstwa, ale dostrzegano już, że w językach istnieją serie wyrazów o takiej samej budowie i podobnych znaczeniach" (Wiśniewska, 1994, s. 227; za: Wincewicz).

W pierwszym z wymienionych fragmentów autor wymienia liczne formy zdrobniałe: żabeczka, robaczek, okienko, sopeleczek, i spieszczone: piękniuchny, chwalebniuchny, ttuściuchny, miękuchny, a także zdrobniałe/spieszczone formy imion dzieci: Jasiek, Jasieczek, Jozefek, Filipek. We fragmencie dotyczącym zgrubień pojawiają się włoskie pary wyrazów typu porta/portone, libro/librone, którym odpowiadają polskie omówienia „nierownie wielki stoł”, „nierownie wielka księga”. Przykłady imion „,naganę lub wzgardę znaczących" to według Styli wyrazy typu chłopisko (od chłop) i niewieścisko (od niewiasta). Warto zauważyć, że dzisiejsze słowniki inaczej kwalifikują wyraz chłopisko - jako potoczny, używany ' $\mathrm{z}$ uznaniem, rzadziej z niechęcią lub pogardą o mężczyźnie' (Pobiły się dwa chłopiska) (USJP).

Wskazanie w podręczniku przykładowych zdrobnień, zgrubień i słów obelżywych jest sygnałem świadomości jego twórcy, że wyrazy pochodne mają inne znaczenie, mogą również wnosić element oceny/emocji osoby mówiącej. O negatywnym nacechowaniu wyrazu pochodnego świadczy łaciński termin vituperativa, odnoszący się do wyrazów 'naganę lub wzgardę znaczących'.

\section{b. Wyrazy nacechowane „ekspresywnie" jako sposób wzbogacania słownictwa i charakterystyczna cecha polszczyzny}

Refleksje na temat ekspresywności języka w dziele S. Kleczewskiego „O początku, dawności, odmianach i wydoskonaleniu języka polskiego" (1767) pojawiają się we fragmencie dziewiątym („Zdaniu”) pt. „O sposobie rozmnożenia słów Polskich” (s. 66-76). Autor pisze w nim o sposobach wzbogacenia słownictwa, m.in. przez przejmowanie zapożyczeń oraz tworzenie neologizmów. Wyraża także przekonanie o bogactwie słów w polszczyźnie: „W języku zaś Polskim mamy tak wiele słow, ktorych po Łacinie wytłumaczyć nie można. Te zaś nie są zbytnie, ale dla większego rzeczy wyrażenia, bardzo potrzebne" (s. 67). S. Kleczewski zwraca uwagę, że słowami takimi są przede wszystkim „słowa umniejszające”, np. maluczki, maluchny, maluty, malusieńki, malusienieczki, których ,nikt dobrze, albo przynajmniej nie tak zwięzle, po Łacinie wytłumaczyć nie

11 Por. przypis 10. 
potrafi” (s. 67). Inną grupą wyrazów niemających łacińskich odpowiedników są polskie imiona typu: Gębaty, Nosal, Kulas, Wilczysko, Pysk, które w ujęciu dzisiejszej onomastyki są przezwiskami. Także np. wyrazu gryzmolić „na inszy język nie wytłumaczy nikt rzetelnie". Jak pokazują przykłady, słownictwo ekspresywne postrzegane było przez Kleczewskiego jako jeden z wyróżników polszczyzny, a język polski uważał za bogatszy pod tym względem od łaciny. Autor dzieła nie używa terminów ekspresywność czy leksyka ekspresywna, niemniej dostrzega występowanie w polszczyźnie nacechowanego ekspresywnie słownictwa i ocenia tę cechę jednoznacznie pozytywnie.

\section{c. O sposobach wyrażania przez mówiącego w języku polskim stosunku uczuciowego i oceny}

Przykładem dawnego podręcznika, w którym opinie o ekspresywności języka wyrażone zostały eksplicytnie, jest „Stylistyka i rytmika polska” K. Wóycickiego (1917). W pierwszym rozdziale dzieła poświęconym synonimice autor zamieścił komentarz merytoryczny, w którym objaśnia, czym jest m.in. „wartość uczuciowa wyrazu”:

Cechy odrębne myślowe, zawarte w znaczeniu wyrazu, nazywamy znaczeniami pobocznemi, a odcień uczuciowy z nim związany, wartością uczuciową. Wartość uczuciowa może wyrażać stosunek uczuciowy mówiącego do przedmiotu, o którym mowa, np. miły, przyjemny, ocenę moralną: dobry, zły, lub estetyczną: piękny, brzydki i t. p. Określenia dodawane przez nas do synonimów, ujawniały ich znaczenia poboczne i wartości uczuciowe: uznanie, szacunek, podziw, cześć, zachwyt, miłość, współczucie, sympatję, potępienie, lekceważenie, niechęć, pogardę, odrazę i t. p. Wartość więc uczuciowa wyrazu, jak widzimy, bywa dodatnia i ujemna (Wóycicki, 1917, s. 8).

K. Wóycicki łączy umiejętność pięknego wysławiania się z właściwym wykorzystaniem wyrazów różniących się pod względem znaczeń pobocznych i wartości uczuciowych. Umiejętność ta - jak pisze - może być wrodzona lub ,zdobyta przez wprawę". Autor ma świadomość, że różnice wrażliwości użytkowników języka w tej kwestii „wywołują nieraz sprzeczne zdania co do znaczeń pobocznych i wartości uczuciowej tego lub innego wyrazu" (s. 8). Innym zagadnieniem, na które zwraca uwagę, jest możliwość wzbogacenia polszczyzny dzięki zdrobnieniom i zgrubieniom. Pisze: „Środki naszego wysłowienia w dziedzinie rzeczowników zbogacają się znacznie przez istnienie w języku form zdrobniałych i powiększających albo zgrubiałych" (s. 11). Przede wszystkim zwraca uwagę na wartość uczuciową zdrobnień i zgrubień. Każe zastanowić się: „Czy rzeczowniki zdrobniałe wyrażają tylko uczucia sympatji [sic! - B.M.], przywiązania, miłości, które żywimy do przedmiotów, istot drobnych, wątłych? Czy nie wyrażają nieraz pogardy, lekceważenia?” (s. 13). W innym miejscu: „Czy rzeczowniki powiększające albo zgrubiałe oznaczają tylko istoty, przedmioty duże?" (s. 14). Zachęca również do ćwiczeń w układaniu zdań uwypuklających znaczenie następujących wyrazów i zwrotów: obojętnie, z obojętnościa, grzecznie, łaskawie, uprzejmie, serdecznie, z góry, z duma, z lekceważeniem, ze wzgarda, pokornie, wyniośle (s. 26). Zauważa, że niektóre wyrazy i zwroty różnią się tylko wartością uczuciową (s. 30). Jednocześnie podkreśla, że czasem trudno jednoznacznie określić, czy dane wyrazy różnią się tylko 
uczuciowo, czy także znaczeniowo (np. Matka Boska, Boża Rodzicielka, Bogarodzica, Matka Boża; s. 30).

Opinie K. Wóycickiego wskazują wyraźnie na jego świadomość zróżnicowania słownictwa pod względem nacechowania ekspresywnego, określanego jako „,wartość uczuciowa wyrazu". Autor zwraca uwagę na zagadnienia istotne w rozważaniach na temat ekspresywności języka, w tym na zróżnicowane nacechowanie emocjonalne zdrobnień i zgrubień, znaczenie pragmatyczne zwrotów i wyrażeń, akcentując możliwość wystąpienia jedynie różnicy „uczuciowej” między wyrazami. Według Władysława Sawryckiego na teorię K. Wóycickiego miał zapewne wpływ Charles Bally, o czym świadczy m.in. zwrócenie uwagi na silny aspekt uczuciowy języka (Sawrycki, 1984, s. 32; za: Decyk-Zięba, online1).

\section{d. Zróżnicowanie wyrazów pod względem uczuciowym i wrażeniowym}

$\mathrm{Na}$ aspekt uczuciowy języka zwrócił uwagę również J. Łoś w drugiej części „Gramatyki polskiej”, poświęconej słowotwórstwu (Łoś, 1925). Tytułem, a zarazem tematem jednego z rozdziałów jest bowiem „Pierwiastek uczuciowy i wrażeniowy w wyrazach”. Autor omawia w nim kilkanaście zagadnień szczegółowych, m.in. związek między stroną uczuciową a wyobrażeniową, zależność doboru wyrazów od charakteru i nastroju człowieka, przezwiska i nazwy humorystyczne, transponowanie wrażeń oraz przyrostki i deminutywa ze strony uczuciowej ${ }^{12}$. Łoś stwierdza:

[...] między wyrazami są takie, które same przez się w danej chwili budzą powszechnie we wszystkich członkach pewnej społeczności jednakowe uczucia nie wyłącznie tylko z powodu swej treści pojęciowej. Przekonywamy się o tem, kiedy dla oznaczenia pewnego wyobrażenia używamy przynajmniej dwu synonimów, wtedy bowiem dokonywamy wyboru odpowiednio do swego nastroju ogólnego, albo też odpowiednio do natężenia uczuć, wzbudzanych w nas w chwili mówienia przez omawiany przedmiot, wyrazy bowiem, mające jednakową treść pojęciową, mają zarazem niejednakową moc wzbudzania wyobrażeń (Łoś, 1925, s. 253).

J. Łoś dostrzega, że jedne słowa wiążą się z uczuciem podziwu, zadowolenia i sympatii (rumak, chata), podczas gdy inne wyrażają lekceważenie, niechęć (szkapa, chatupa). W rozważaniach autora gramatyki pojawia się określenie „siła ekspresyjna wyrazów”. Dostrzega on zależność między siłą ekspresyjną wyrazów a „wdziękiem” czy „brutalnością”; jako przykład podaje „silniejsze” słowo zdechnać obok ,słabszego” umrzeć. J. Łoś pisze także o wyrażaniu ujemnego stosunku do drugiego człowieka przez używanie przezwisk ${ }^{13}$ derywowanych od nazw zwierząt domowych (np. krowa, baran, świnia)

12 Wymienione zagadnienia to tytuły wybranych części analizowanego rozdziału podręcznika J. Łosia.

13 Wyrazu przezwisko w kontekście apelatywnych ekspresywizmów osobowych powstałych w wyniku derywacji semantycznej od nazw zwierząt używa autor w jednym ze znaczeń funkcjonujących w języku ogólnym, tj. szczególnie 'nazwa obelżywa, uszczypliwa' (SW), współcześnie ‘obelżywa nazwa, wyzwisko' (USJP). W onomastyce termin przezwisko klasyfikowany jest jako nazwa nieoficjalna (obok pseudonimu i przydomku), oznacza dodatkową (nieoficjalną) nazwę własną nadawaną określonej osobie (Gałkowski, Bijak, 2018). 
lub dzikich (lis, niedźwiedź, wilk), a także części ciała (kiep, ostry języczek). Ponadto ocenia, że „,[w]ybitnie uczuciowy charakter mają przeniesienia z wrażeń zmysłowych do dziedziny duchowej", np. czarny charakter, szorstko odpowiadać, chropowatość obyczajów, jasny 'zrozumiały', miękkie serce, goraca modlitwa (Łoś, 1925, s. 257-258). W kontekście budowy słowotwórczej wyrazów dostrzega także to, że „użycie pewnego przyrostka nadaje wyrazowi szczególny uczuciowy odcień znaczenia", tj. niektóre wywołują wrażenia raczej dodatnie, inne - ujemne (bydlę - bydlak, dziewcze - dziewczak, dziecko - dzieciak; Łoś, 1925, s. 259). Typowym tego przykładem są deminutiwa bialutki, mięciutki, nowiusieńki, charakterystyczne zwłaszcza dla kontaktów językowych z dziećmi, poezji i języka ludu. Mowa także o „temperaturze uczuciowej wyrazów”, która „bywa powyżej lub poniżej zera” (Łoś, 1925, s. 260).

W tym podrozdziale przedstawiono siedemnastowieczny podręcznik do nauki języka włoskiego autorstwa A. Styli, oświeceniowe dzieło S. Kleczewskiego, podręcznik z ćwiczeniami ze stylistyki i rytmiki polskiej K. Wóycickiego oraz pierwszą gramatykę historyczną języka polskiego J. Łosia. Przyjęte w artykule kryterium czasowe zakładało dobór prac powstałych w różnych okresach, co jednocześnie oznaczało wzięcie pod uwagę prac różnego typu, charakterystycznych zarówno dla przednaukowego, jak i naukowego etapu rozwoju językoznawstwa polskiego (Urbańczyk, 1993, s. 8, za: Decyk-Zięba, online2). Do pierwszego z wymienionych etapów przynależą prace A. Styli i S. Kleczewskiego, do drugiego natomiast - opracowania K. Wóycickiego i J. Łosia. W tym kontekście nie jest zaskoczeniem, że prace te wykazały wyraźne zróżnicowanie użytej terminologii. Wnioski z analizy dawnych gramatyk znajdują się w zakończeniu.

\section{Terminy związane z ekspresywnością języka i leksyką ekspresywną w wybranych współczesnych polskich pracach językoznawczych}

Przedmiotem zainteresowania autorki w tej części artykułu są dotychczasowe ustalenia terminologiczne czworga badaczy na temat ekspresywności języka i ekspresywizmów. Z uwagi na obszerność literatury poświęconej tej tematyce oraz ograniczone ramy niniejszego artykułu konieczne okazało się dokonanie arbitralnego wyboru tekstów poddanych naukowej refleksji. Odwołano się do opracowań, w których badacze podjęli próbę zdefiniowania podstawowych terminów związanych ekspresywnością języka i leksyką ekspresywną oraz poruszyli temat zróżnicowania słownictwa ekspresywnego, wskazując na podziały ekspresywizmów lub proponując ich autorskie klasyfikacje. Kryterium wyboru tekstów był również czas ich powstania - wybrano jedynie te prace, które zostały opublikowane w ostatnim półwieczu ${ }^{14}$. Powyższe ograniczenia

${ }^{14}$ Zgodnie z tym kryterium omawiane prace przedstawione zostały w porządku chronologicznym. Taki układ treści nawiązuje do wcześniejszego rozdziału, w którym dawne gramatyki i podręczniki również zaprezentowano zgodnie z następstwem czasowym. Analogicznie do wcześniejszej części artykułu każdy fragment poświęcony omówieniu poglądów danego badacza poprzedzony jest tytułem wskazującym na główne zagadnienia w nim poruszane. 
w zamierzeniu autorki miały, z jednej strony, zawęzić bogatą literaturę przedmiotu, a z drugiej - umożliwić prześledzenie poglądów współczesnych badaczy na wymienione zagadnienia. Kierując się takimi wytycznymi, zdecydowano o przedstawieniu ustaleń Teresy Skubalanki $\left(1972^{15}, 1973^{16}\right)$, Stanisława Grabiasa $(1978,1981)$, Haliny Zgółkowej (1991) oraz Artura Rejtera (2006) ${ }^{17}$.

\section{a. Ekspresywność - czym jest i w jaki sposób może być wyrażona?}

Ważnym studium poświęconym ekspresywności języka w ujęciu teoretyczno-językoznawczym jest artykuł T. Skubalanki z 1972 r., zatytułowany „O ekspresywności języka” (za: Skubalanka, 1995a). Ekspresywność jest w nim rozumiana jako „określona właściwość elementów językowych”, nabyta w wyniku ekspresji ${ }^{18}$, czyli operacji językowej (oznacza ona obecność funkcji tzw. ekspresywnej w sytuacji komunikacji językowej ${ }^{19}$ ) (Skubalanka, 1995a, s. 60).

Autorka wskazuje, że spośród językoznawców zajmujących się zagadnieniem ekspresywności w ujęciu teoretycznym kluczowa jest rozprawa Ch. Bally’ego z 1966 r.,

${ }^{15}$ Artykuł został przedrukowany w tomie „O stylu poetyckim i innych stylach języka” (Skubalanka, 1995a, s. 59-67). W niniejszym opracowaniu korzystano z przedruku.

${ }^{16}$ Artykuł został przedrukowany w tomie „O stylu poetyckim i innych stylach języka” (Skubalanka 1995b, s. 68-71). W niniejszej pracy korzystano z przedruku.

17 Przykładową listę tematów prac poświęconych ekspresywności języka wraz z licznymi odnośnikami bibliograficznymi podaje A. Rejter. Są to np.: ekspresja słowotwórcza, wpływ nowo pojawiającego się słownictwa ekspresywnego na kształt komunikacji społecznej, typy i funkcja ekspresywizmów w tekstach literackich (staropolskich i późniejszych), analiza ekspresywizmów w aspekcie badań dialektologicznych (Rejter, 2006, s. 62). Wśród najnowszych publikacji książkowych na temat ekspresywizmów warto wymienić monografię Natalii Siudzińskiej „Formacje ekspresywne we współczesnym języku polskim (na przykładzie wybranych pospolitych nazw osobowych)" (2016). W części teoretycznej autorka wymienia lub omawia prace polskich językoznawców poświęcone nacechowaniu ekspresywnemu lub stylistycznemu derywatów, w tym m.in. opracowania dotyczące formacji deminutywnych i augmentatywnych (np. Grzegorczykowa, 1978; Buttler 1979), publikacje z zakresu stylistyki (np. Lubaś, 2003) czy prace na temat ekspresywności na poziomie słowotwórstwa rzeczownika (Warchoł, 1974). W obu monografiach - A. Rejtera i N. Siudzińskiej - znajduje się bogata literatura przedmiotu.

18 Zagadnienie ekspresji podejmuje również Anna Wierzbicka w pracy „Dociekania semantyczne” (1969). W rozdziale zatytułowanym „Problemy ekspresji. Ich miejsce w teorii semantycznej” autorka stwierdza: „Wypowiedź przedstawia się [...] jako potok ekspresji życia wewnętrznego osoby mówiącej. Praca słuchacza polega na równoległym z obserwacją owego, szczerego czy udanego, potoku ekspresji, konstruowaniu ciągu hipotez (sądów), czyli na modelowaniu życia wewnętrznego osoby mówiącej. A zadanie lingwisty-semantyka można widzieć w modelowaniu owej modelującej pracy słuchacza" (Wierzbicka, 1969, s. 36). W dalszej części rozdziału dokonuje przeglądu różnorodnych faktów językowych o charakterze ekspresywnym i apelatywnym oraz dla każdego proponuje zapis semantyczny oparty na schematach: Saqdze, $\dot{z} e \ldots$, Chcę, że..., Nie chcę, żeby..., Czuję, że... (Wierzbicka, 1969, s. 40 i in.). Do problemu ekspresji językowej w ujęciu Wierzbickiej odwołuje się Stanisław Grabias, przejmując jej metodę analizy wypowiedzeń emocjonalnych (1981, s. 14-15, 31-33 i in.).

19 Wyróżnienie ekspresywnej funkcji języka (obok impresywnej i symbolicznej) wprowadził Karl Bühler w 1934 r. w dziele „Teoria języka” (,Sprachtheorie”). 
w której autor utożsamia ekspresywność językową z afektywnością (emocjonalnością) języka, wprowadza wiele odcieni znaczeniowych do definicji ekspresywności, odróżnia ekspresywność językową od indywidualnej (charakterystycznej dla tekstów językowych parole) oraz sytuacyjnej, okazjonalnej, również właściwej tekstom (Skubalanka, 1995a, s. 61). Według autorki badanie funkcji ekspresywnej wykracza poza ramy językoznawstwa, badanie ekspresywności mieści się natomiast w obrębie pragmatyki języka (Skubalanka, 1995a, s. 66).

Zaproponowany przez T. Skubalankę podział znaków językowych na: znaki o utajonej ekspresywności („,nieekspresywne”, np. użycie wyrazu ojczyzna w wyrażeniu ojczyzna Goethego, a użycie ekspresywne w ,inwokacji”: Litwo! Ojczyzno moja!); konwencjonalne znaki o wyrazistej ekspresywności (synuś); niekonwencjonalne znaki ekspresywne (towar jako określenie młodej dziewczyny w gwarze studenckiej) (Skubalanka, 1995a, s. 65). W innym artykule - „Ekspresywność języka a mowa potoczna” (Skubalanka, 1995b) - autorka wymienia m.in. następujące słowotwórczo-leksykalne środki wyrażania ekspresywności: synonimy ekspresywne (psiora 'psiara', Polus 'Polak'), przymiotniki i przysłówki waloryzujące (klawo, fajnie), tytuły grzecznościowe (panowie! (do kolegów)), partykuły modalne i przekleństwa (chulerka 'cholerka'). Zwraca również uwagę na zdrobnienia grzecznościowe występujące w gwarze miejskiej (w porzqdeczku, pomidorki) (Skubalanka, 1995b, s. 69).

\section{b. Znak ekspresywny a komponent emocjonalny i wartości ekspresywne wypowiedzi}

W 1978 r. Stanisław Grabias w artykule „Pojęcie językowego znaku ekspresywnego” postawił pytanie badawcze: $\mathrm{z}$ jakimi jednostkami języka łączyć zjawisko ekspresywności? ${ }^{20}$. Definiując znak ekspresywny, pisał: „Za ekspresywne uznaję te znaki semiotyczne, za pomocą których nadawca wyraża swój stosunek do otaczających go zjawisk lub w których niezależnie od intencji nadawcy przejawiają się cechy jego osobowości" (Grabias, 1978, s. 107). W opinii autora czystych znaków ekspresywnych należy szukać wśród znaków semiotycznych (znaków niejęzykowych, takich jak np. gesty zniecierpliwienia, oznaki radości czy zdenerwowania) (tamże). Służą one bowiem wyłącznie celom ekspresywnym. Tak rozumiany znak ekspresywny jest indeksem (oznaką), zjawiskiem motywowanym, jak dym będący oznaką ognia czy chmura oznaczająca deszcz. W przypadku znaków językowych związek elementu znaczonego i znaczącego opiera się na dowolności (arbitralności).

Emocjonalne wyrażenie stosunku nadawcy do komunikowanej rzeczywistości odbywa się jedynie w wypowiedzeniach (zamierzona postawa emocjonalna). Jako przykład wymienia rozmaite uczucia wywoływane przez kontakt z osobą, o której sądzimy, że jest „głupia”, m.in.: To baran! (oburzenie), Oj, cymbat z niego cymbat (politowanie),

${ }^{20}$ Drugie z postawionych pytań brzmiało: w jakim stosunku pozostaje ekspresywny komponent znaku do komponentów intelektualnych? (Grabias, 1978, s. 107). Zmodyfikowana i poszerzona wersja artykułu znalazła się w książce autora pt. „O ekspresywności języka” (Grabias, 1981, s. 28-40). 
Cóż taka miernota może powiedzieć? (lekceważenie). W takich wypowiedziach komponent emocjonalny jest ,składnikiem znaczenia wypowiedzi pojmowanego w opozycji do informacji i rozumianego za M.R. Mayenową jako wartość inwariantna, wynikająca ze znaczenia wyrazów i form, realizowanego w określonej ramie modalno-emocjonalnej" (Grabias, 1978, s. 112). Ponadto wypowiedź niesie wartości ekspresywne niezależne od intencji nadawcy, które wiążą się z natężeniem i barwą głosu, tempem wypowiedzi itp. (tamże).

Badacz wyraźnie odróżnia emocjonalność wyrazu od elementów ekspresywnych pozostających poza emocjonalnością, których wyraz jest także nosicielem (s. 113). Jako przykład analizuje wyraz grubas, który można zinterpretować jako budzący uczucia ujemne. Aktualizacja w tekście wskazuje, o jakie dokładnie uczucia w danym akcie komunikacyjnym chodzi: Ty chodzisz z tym grubasem? (zdziwienie), Nie lubię tego grubasa (zdenerwowanie), Oj ty grubasie (politowanie) itp.

Ważna konstatacja pojawia się także w zakończeniu artykułu, gdy autor wyraża opinię, że ,„w] obrębie wyrazów emocjonalnych można wydzielić przykłady o eksplicytnych wykładnikach emocjonalności oraz wyrazy, w których emocjonalność tkwi implicite". Pierwszą grupę tworzą np. wyrazy z formantami wyspecjalizowanymi w tworzeniu derywatów ekspresywnych oraz wyrazy o znaczeniu przenośnym (tzw. przenośnie sferyczne). Do drugiej grupy należą wyrazy ujemnie nacechowane, w których brakuje zewnętrznego wykładnika emocjonalności (s. 114-115).

W późniejszej książce „O ekspresywności języka. Ekspresja a słowotwórstwo” do przykładów wyrazów ekspresywnych motywowanych znaczeniowo autor dołączył także wyrazy motywowane procesami skojarzeniowymi, aluzjami (np. dręcznik 'podręcznik' niesie aluzję do wyrazu dręczyć, kimać 'spać' przywołuje środowiska przestępcze, biesiada ewokuje styl książkowy) (Grabias, 1981, s. 40). W pracy tej ekspresywność rozumiana jest jako cecha znaku będąca pochodną ekspresji, czyli procesu uzewnętrzniania osobowości nadawcy (s. 22). Warto wspomnieć, że autor przedmiotem opisu uczynił wyrazy o ekspresywności eksplicytnej, analizując leksykalne środki ekspresji: ekspresywność formantów, ekspresywność wyrazów niepodzielnych słowotwórczo, neologizmy jako środek ekspresji, aluzję leksykalną. Dostrzega również różnice między formacjami prymarnie ekspresywnymi (gościunio) i sekundarnie ekspresywnymi (zgrywa, pyskacz).

\section{c. Ekspresywność języka w kontekście odmian stylowych polszczyzny}

O ekspresywności języka jako ważnym parametrze wyróżniania odmian stylowych współczesnej polszczyzny pisze Halina Zgółkowa w artykule „Leksyka ekspresywna jako wyróżnik potocznej odmiany współczesnej polszczyzny” (1991). Podkreśla, że emocjonalna wartość słów jest ich niezbywalną własnością, która funkcjonuje we wszystkich procesach komunikacyjnych (Zgółkowa, 1991, s. 45). Badaczka zauważa: „Można [...] wyodrębnić w zasobie leksykalnym każdego języka kategorie słów, które 
swoją funkcję ekspresywną realizują w sposób szczególnie widoczny, wyrazisty. Można wskazać takie słowa, których wartość ekspresywna jest szczególnie dobitnie zaznaczona dzięki specyficznej budowie gramatycznej” (tamże). W swoich badaniach wyróżnia ekspresywizmy wyodrębnione według kryterium semantyczno-morfologicznego (zdrobnienia i zgrubienia) oraz według kryterium semantyczno-pragmatycznego (ekspresywizmy pragmatyczne).

Na podstawie analizy list frekwencyjnych sporządzonych dla prób materiału językowego w siedmiu odmianach współczesnej polszczyzny H. Zgółkowa dostrzega znaczne różnice w produktywności formantów zdrabniających i spieszczających w różnych odmianach języka, np. w tekstach publicystycznych, w polszczyźnie dziecięcej, prozie artystycznej oraz w polszczyźnie mówionej dorosłych (s. 49). Ocenia, że zgrubienia we współczesnym języku polskim są kategorią leksykalno-gramatyczną występującą stosunkowo rzadko (s. 50). Ekspresywizmy pragmatyczne występują zaś głównie w dramacie i prozie artystycznej. Badania H. Zgółkowej dowodzą, że ekspresywizmy są jednym z najważniejszych wyznaczników potocznej odmiany polszczyzny (s. 52).

\section{d. Ekspresywność a zagadnienia potoczności i wartościowania}

Monografia A. Rejtera „Leksyka ekspresywna w historii języka polskiego. Kulturowo-komunikacyjne konteksty potoczności” (2006) to szczegółowe studium poświęcone ekspresywnym apelatywnym nazwom osób. W części teoretycznej, zatytułowanej „Wokół ekspresywności”, autor kreśli dotychczasowy stan badań nad zagadnieniem ekspresywności w literaturze polskiej i zagranicznej. Doprecyzowując rozumienie terminu ekspresywność w odniesieniu do pojęć ekspresji i emocjonalności, odwołuje się do ustaleń S. Grabiasa: „,...] ekspresja ${ }^{21}$ jest procesem uzewnętrzniania osobowości nadawcy, ekspresywność [...] jest cechą znaku będącą pochodną, skutkiem owego procesu. Emocjonalność natomiast stanowi uczuciowy stosunek nadawcy do rzeczywistości ekstralingwistycznej, wyrażony za pomocą środków językowych" (Rejter, 2006, s. 57-58). Podkreśla przy tym związek ekspresywnego znaku językowego z potoczną odmianą polszczyzny, uwidaczniającą się w tekstach nieoficjalnych, spontanicznych. Zwraca również uwagę m.in. na problem wartościowania, łączący się bezpośrednio z zagadnieniem ekspresywności znaku językowego (s. 67).

W kontekście rozważań na temat terminologii związanej z ekspresywnością języka i leksyką ekspresywną istotna jest zaproponowana przez autora typologia ekspresywizmów leksykalnych, która - jak wskazuje autor - stanowi wypadkową koncepcji S. Grabiasa, H. Zgółkowej oraz jego własnej (s. 62-63). Uwzględnia ona ogólny podział na ekspresywizmy derywowane oraz pragmatyczne. Szczegółowe rozróżnienia tych typów przedstawia tabela.

${ }^{21}$ Wyróżnienia w cytacie są zgodne z oryginałem. 
Typologie wyrazów ekspresywnych w ujęciu T. Skubalanki, S. Grabiasa, H. Zgółkowej i A. Rejtera.

\begin{tabular}{|c|c|}
\hline Autor, dzieło, rok wydania & Typologia wyrazów ekspresywnych \\
\hline $\begin{array}{l}\text { T. Skubalanka, } \\
\text { O ekspresywności języka } \\
(1995 a, \text { s. 65) }\end{array}$ & $\begin{array}{l}\text { I. Znaki o utajonej ekspresywności („nieekspresywne”, } \\
\text { np. ojczyzna) } \\
\text { II. Konwencjonalne znaki o wyrazistej ekspresywności (synuś) } \\
\text { III. Niekonwencjonalne znaki ekspresywne (towar w znaczeniu } \\
\text { (młoda dziewczyna') }\end{array}$ \\
\hline $\begin{array}{l}\text { S. Grabias, } \\
\text { O ekspresywności języka. } \\
\text { Ekspresja a słowotwórstwo } \\
(1981, \text { s. 40) }\end{array}$ & $\begin{array}{l}\text { I. Wyrazy o ekspresywności implicytnej (guzdracz, oferma) } \\
\text { II. Wyrazy o ekspresywności eksplicytnej: } \\
\text { 1) motywowane formalnie, tj. ekspresywnie nacechowanymi } \\
\text { morfemami lub fonemami (tysol, mięcho, ptaszuś) } \\
\text { 2) motywowane znaczeniowo: } \\
\text { a) zmianami w sferze znaczenia leksykalnego (baran 'głu- } \\
\text { piec', pień 'głuchy') } \\
\text { b) procesami skojarzeniowymi, aluzjami (dręcznik 'pod- } \\
\text { ręcznik': dręczyć, pot. zalulać się 'upić się - ewokuje } \\
\text { potoczność) }\end{array}$ \\
\hline $\begin{array}{l}\text { H. Zgółkowa, } \\
\text { Leksyka ekspresywna } \\
\text { jako wyróżnik potocznej } \\
\text { odmiany współczesnej pol- } \\
\text { szczyzny } \\
(1991, \text { s. } 45-52)\end{array}$ & $\begin{array}{l}\text { I. Ekspresywizmy morfologiczne (zdrobnienia i zgrubienia): } \\
\text { człowieczek, budyneczek, komentarzyk, lizaczek, spacerek, } \\
\text { pingwinek } \\
\text { II. Ekspresywizmy pragmatyczne: bumelować, bumelant, par- } \\
\text { tolić, psioczyć, spartaczyć, odfajkowanie, rzępolenie, bachor, } \\
\text { knajpa, barachto, bajzel }\end{array}$ \\
\hline $\begin{array}{l}\text { A. Rejter, } \\
\text { Leksyka ekspresywna } \\
\text { w historii języka polskiego. } \\
\text { Kulturowo-komunikacyjne } \\
\text { konteksty potoczności } \\
\text { (2006, s. 63-67) }\end{array}$ & $\begin{array}{l}\text { I. Ekspresywizmy derywowane właściwe: skromniś - na okreś- } \\
\text { lenie osoby skromnej, niepozornej od skromny SL; niezbed- } \\
\text { nik - określenie osoby złej, o niskiej wartości moralnej od } \\
\text { niezbedny 'budzący niechęć, odrazę, plugawy, nikczemny, } \\
\text { paskudny' SXVI - znaczenie podstawy jest eksplicytnie wyra- } \\
\text { żone w nazwie i dotyczy głównej waloryzowanej w niej cechy } \\
\text { II. Ekspresywizmy derywowane asocjacyjne: kosztowniczek na } \\
\text { określenie osoby kapryśnej od kosztowny 'wiele wartający, } \\
\text { szacowny, wyborny, znakomity; smaczny' SL - cecha przy- } \\
\text { pisywana osobie nazywanej nie jest eksplicytnie wyrażona } \\
\text { w nazwie derywowanej } \\
\text { III. Ekspresywizmy derywowane kompozycyjne: kopcidym } \\
\text { paskudny kucharz, partacz' SL; płóczyflak 'kopcidym, } \\
\text { kuchta' SL } \\
\text { IV. Ekspresywizmy pragmatyczne pierwotne - jednostki o eks- } \\
\text { presywności implicytnej, niederywowane (ani morfologicznie, } \\
\text { ani semantycznie), które niezależnie od kontekstu charaktery- } \\
\text { zuje nacechowanie emocjonalne, np. cham, gbur } \\
\text { V. Ekspresywizmy pragmatyczne wtórne - jednostki o eks- } \\
\text { presywności implicytnej wynikającej ,z różnego rodzaju } \\
\text { zabiegów sekundarnych względem znaczenia leksykalnego, } \\
\text { najczęściej o charakterze metaforycznego rozszerzenia (prze- } \\
\text { sunięcia) tegoż bądź aluzji” (Rejter, 2006, s. 66), szeroko } \\
\text { rozumiane neosemantyzmy, np. prosiak, flądra, kościotrup } \\
\text { jako określenia osoby }\end{array}$ \\
\hline
\end{tabular}

Typologię w ujęciu S. Grabiasa przytaczam za autorem (Grabias, 1981, s. 40). Pozostałe typologie: opracowanie własne na podstawie wymienionych publikacji. 
W tym podrozdziale zaprezentowano wybrane prace polskich lingwistów na temat ekspresywności języka i leksyki ekspresywnej z ostatnich 50 lat. Podsumowanie tych rozważań oraz omówienie materiału zgromadzonego w tabeli znajduje się w zakończeniu.

\section{Zakończenie}

Niniejszy artykuł stanowi próbę syntetycznego omówienia najważniejszych ustaleń na temat ekspresywności języka i leksyki ekspresywnej w ujęciu historycznym na podstawie wybranych dawnych gramatyk (A. Styli, S. Kleczewskiego, K. Wóycickiego oraz J. Łosia) oraz współczesnych prac językoznawczych (T. Skubalanki, S. Grabiasa, H. Zgółkowej i A. Rejtera). Uzasadnieniem wyboru publikacji różnego typu powstałych w różnych okresach była chęć pokazania, jak kształtowała się polska terminologia związana z tą tematyką.

Wśród omówionych dawnych gramatyk zwraca uwagę ich niejednorodność, zarówno pod względem czasu powstania, formy, przeznaczenia, jak i użytej terminologii. Mając świadomość, że między XVI a XVIII w. gramatyki miały charakter użytkowy, służyły cudzoziemcom do nauki języka polskiego lub były pomocą dla Polaków w nauczaniu języków obcych, dzieło A. Styli można uznać za typowy przykład gramatyki tamtego czasu. Rozważania o zdrobnieniach, zgrubieniach i słowach obelżywych autor zamieścił w trzech krótkich podrozdziałach w części poświęconej imionom (tj. rzeczownikom i przymiotnikom). W czasach, gdy nie istniały znane dziś terminy ekspresywność czy ekspresywizm, autor, omawiając różnice semantyczne czy „ekspresywne” wyrazów pochodnych, stosował terminy łacińskie, które objaśniał w języku polskim (zob. diminutiva, augmentativa, vituperativa).

Celem gramatyk ukazujących się od lat siedemdziesiątych XVIII w. było kształcenie umiejętności językowych Polaków. Ten trend zaznaczył się wyraźnie w okresie rozbiorów. Dzieło S. Kleczewskiego z 1767 r. - jak ocenia W. Decyk-Zięba - włącza się do dyskusji na temat kondycji ówczesnego języka polskiego (Decyk-Zięba, online1). Autor poświęca szczególną uwagę dziejom języków słowiańskich, pochodzeniu języka polskiego, słownictwu i sposobom jego wzbogacenia, ówczesnej normie językowej itp. Pisząc o bogactwie polszczyzny, podkreśla, że w języku polskim jest wiele wyrazów, które nie mają adekwatnych odpowiedników w łacinie (m.in. maluczki, Gębaty, gryzmolić). Jak ocenia autor, są one potrzebne w języku i służą lepszemu „wyrażaniu” rzeczy. A zatem słownictwo ekspresywne postrzega S. Kleczewski jako jeden z wyróżników polszczyzny, wskazujący na bogatszy zasób leksykalny w porównaniu z łaciną. W swojej pracy - podobnie jak A. Styla - nie posługuje się terminami odnoszącymi się do ekspresywności w języku czy leksyki ekspresywnej.

Analiza dwóch prac o charakterze naukowym wykazała, że autorzy zwracają w nich uwagę na aspekt uczuciowy języka. W pracy K. Wóycickiego, w rozdziale poświęconym synonimice, pojawia się bezpośrednio wyrażona refleksja merytoryczna na temat „barwy uczuciowej wyrazu". Podobnie jak w opracowaniach A. Styli czy S. Kleczewskiego, autor obejmuje refleksją naukową zdrobnienia i zgrubienia, mając świadomość, że wyrażają 
one rozmaite uczucia (np. miłości, przywiązania, ale też pogardy czy lekceważenia). Dostrzega ponadto m.in. różnice w znaczeniu pragmatycznym zwrotów i wyrażeń. J. Łoś w części swego dzieła poświęconej słowotwórstwu zwrócił natomiast uwagę na aspekt uczuciowy języka. Podobnie jak wcześniejsi autorzy, zauważa, że wyrazy wyrażają różne uczucia (podziwu, sympatii, niechęci itp.), w tym kontekście mówi o „sile ekspresyjnej wyrazów” oraz „temperaturze uczuciowej”. Obie prace dowodzą, że w pierwszym trzydziestoleciu XX w. twórcy gramatyk mieli świadomość zróżnicowania ekspresywnego wyrazów, a także funkcji pragmatycznej ekspresywizmów.

Zgodnie z założeniami niniejszego artykułu w drugiej części opracowania przedmiotem zainteresowania uczyniono wybrane publikacje, w których polscy lingwiści podjęli refleksje nad terminami ekspresywność, ekspresja, znak ekspresywny, ekspresywizm oraz zwrócili m.in. uwagę na zróżnicowanie leksyki ekspresywnej (zob. tabelę). Przedstawione prace nie tylko omawiają kluczowe terminy z zakresu ekspresywności języka i leksyki ekspresywnej, ale również podejmują lub sygnalizują wiele innych istotnych zagadnień dotyczących tej tematyki, takich jak np. ekspresywność w kontekście słowotwórstwa i pragmatyki, sposoby wyróżniania ekspresywizmów, ekspresywność/ emocjonalna wartość słów jako właściwość elementów językowych, emocjonalne wyrażanie stosunku nadawcy do komunikowanej rzeczywistości, produktywność formantów zdrabniających i spieszczających w różnych odmianach polszczyzny, ekspresywność języka a badanie potoczności lub wartościowania. Wymieniony zestaw tematów czy też problemów badawczych pokazuje szeroką perspektywę, w jakiej prowadzone są badania nad ekspresywnością języka i leksyką ekspresywną w polskiej lingwistyce.

Na podstawie poczynionych obserwacji warto podkreślić, że w typologii ekspresywizmów uwydatnia się nadrzędny podział na wyrazy z ekspresywnością wyrażoną implicytnie i eksplicytnie. Badacze zwracają również uwagę na to, czy ekspresywizm jest / nie jest jednostką derywowaną słowotwórczo lub semantycznie. Warto dodać, że w ujęciach typologicznych ekspresywizmy niederywowane oraz derywowane wyłącznie semantycznie nazywa się pragmatycznymi, sytuując rozważania na temat ich użycia w obszarze pragmatyki językowej ${ }^{22}$. W kontekście planowanych przez autorkę historycznych badań pragmalingwistycznych nad ekspresywnością i ekspresywizmami warte podkreślenia jest stwierdzenie S. Grabiasa, że emocjonalne wyrażanie stosunku nadawcy do komunikowanej rzeczywistości odbywa się w wypowiedzeniach. A zatem - zasygnalizowane we wstępie artykułu - badania dawnego dialogu na podstawie Korpusu dawnych polskich tekstów dramatycznych (1772-1939) pod kątem różnych sposobów przejawiania się ekspresywności w wypowiedziach konkretnych postaci zróżnicowanych pod względem płci, wieku i statusu społecznego, a także nasycenia dialogu ekspresywizmami, pozwolą na prześledzenie podobieństw i różnic między ekspresywnością dawną a współczesną.

Powyższe rozważania skłaniają również autorkę do podjęcia dalszych badań poświęconych kształtowaniu się terminologii z zakresu ekspresywności języka oraz leksyki

${ }^{22}$ Warto wspomnieć, że w kontekście pragmatyki, a dokładnie pragmatyki słowotwórczej, funkcję ekspresywną omawia Iwona Kaproń-Charzyńska (2014). 
ekspresywnej w języku polskim. W kolejnym opracowaniu przedmiotem jej zainteresowania będzie zaczerpnięty z podręcznika A. Styli termin vituperativa, jego pochodzenie, zastosowanie w dawnych gramatykach i źródłach leksykograficznych w kontekście kształtowania się polskich kwalifikatorów ekspresywnych (obelżywy, pogardliwy, lekceważacy, obraźliwy).

Przeprowadzona analiza wybranych dawnych gramatyk oraz współczesnych prac językoznawczych z całą pewnością nie wyczerpuje zasygnalizowanego w tytule artykułu zagadnienia. Decyzja o uwzględnieniu czterech dawnych gramatyk oraz omówienie wybranych prac czworga językoznawców z ostatniego półwiecza determinuje wnioski płynące $z$ analizy tak dobranego materiału. W tym kontekście mowa zatem o zarysie badań, a nie o rozstrzygnięciach końcowych. Liczba dzieł, których dotyczy refleksja naukowa, oraz ich duże zróżnicowanie powodują, że dotychczasowe obserwacje należy traktować jako przyczynek do dalszych pogłębionych studiów opartych na materiale językowym zaczerpniętym zarówno z większej liczby dawnych gramatyk, tekstów jednorodnych gatunkowo (pisanych nie tylko w języku polskim), jak i literatury przedmiotu, nieuwzględnionej w niniejszym artykule. Umożliwi to poszerzenie, pogłębienie i weryfikację ustaleń zaprezentowanych w tym opracowaniu.

\section{Bibliografia}

Buttler, D. (1979). Powojenne ekspresywizmy polskie. Prace Filologiczne, XXIX, s. 85-90.

Decyk-Zięba, W. (online). Stanisław Kleczewski, „O początku, dawności, odmianach i wydoskonaleniu języka polskiego. Zdania...”. Lwów 1767. Pobrane z https://gramatyki.uw.edu.pl/book/517 (12.08.2019).

Decyk-Zięba, W. (online). Z historii gramatyk języka polskiego. Pobrane z https://gramatyki.uw.edu.p1/ history (15.10.2020).

Gałkowski, A., Bijak U. (tłum. i oprac.) (2018). Lista ICOS kluczowych terminów onomastycznych (online). Grupa Terminologiczna ICOS International Council of Onomastic Sciences. Łódź-Kraków. Pobrane z http://onomastyka.uni.lodz.pl/wp-content/uploads/2019/03/Lista-ICOS-kluczowychtermin\%C3\%B3w-onomastycznych.pdf (12.10.2020).

Grabias, S. (1978). Pojęcie językowego znaku ekspresywnego. W: M. Szymczak (red.), Z zagadnień stownictwa współczesnego języka polskiego (s. 107-115). Wrocław-Warszawa-Kraków-Gdańsk: Zakład Narodowy im. Ossolińskich.

Grabias, S. (1981). O ekspresywności języka. Ekspresja a słowotwórstwo. Lublin: Wydawnictwo Lubelskie.

Grzegorczykowa, R. (1978). Struktura semantyczna wyrażeń ekspresywnych. W: M. Szymczak (red.), Z zagadnień słownictwa wspótczesnego języka polskiego (s. 117-123). Wrocław-Warszawa-KrakówGdańsk: Zakład Narodowy im. Ossolińskich.

Kaproń-Charzyńska, I. (2014). Pragmatyczne aspekty stowotwórstwa. Funkcja ekspresywna i poetycka. Toruń: Wydawnictwo Naukowe UMK.

Kleczewski, S. (1767). O początku, dawności, odmianach $i$ wydoskonaleniu języka polskiego. Zdania. Lwów. Pobrane z https://polona.pl/item/o-poczatku-dawnosci-odmianach-y-wydoskonaleniu-jezyka-polskiego-zdania,ODYwMzQ/1/\#info:metadata (12.08.2019).

Lubaś, W. (2003). Polskie gadanie. Podstawowe cechy i funkcje potocznej odmiany polszczyzny. Opole: Wydawnictwo Uniwersytetu Opolskiego. 
Łoś, J. (1925). Gramatyka polska. Cz. II: Słowotwórstwo. Lwów-Warszawa-Kraków: Wydawnictwo Zakładu Narodowego im. Ossolińskich. Pobrane z polona.pl/item/gramatyka-polska-cz-2-slowotworstwo,MT E3NzI0OTk/6/\#info:metadata (12.08.2019).

Mitrenga, B., Pastuch, M., Wąsińska, K. (w druku). Możliwości i ograniczenia historycznych badań pragmalingwistycznych. W: M. Mączyński, E. Horyń, E. Zmuda (red.), W kręgu dawnej polszczyzny. Kraków: Akademia Ignatianum: Wydawnictwo WAM.

Rejter, A. (2006). Leksyka ekspresywna w historii języka polskiego. Kulturowo-komunikacyjne konteksty potoczności. Katowice: Wydawnictwo Uniwersytetu Śląskiego.

Sawrycki, W. (1984). Wspóltwórcy szkolnej polonistyki dwudziestolecia międzywojennego (Kazimierz Wóycicki, Konstanty Wojciechowski, Juliusz Kleiner, Konrad Górski). Warszawa-Poznań-Toruń: PWN.

Siudzińska, N. (2016). Formacje ekspresywne we wspótczesnym języku polskim (na przykładzie wybranych pospolitych nazw osobowych). Warszawa: Wydział Polonistyki UW, BEL Studio Sp. z o.o.

Skubalanka, T. (1995a). O ekspresywności języka. W: eadem, O stylu poetyckim i innych stylach języka. Studia i szkice teoretyczne (s. 59-67). Lublin: Wydawnictwo UMCS. [Pierwodruk: Skubalanka, T. (1972). O ekspresywności języka. Annales UMCS, Sectio F, 1992, s. 123-135].

Skubalanka, T. (1995b). Ekspresywność języka a mowa potoczna. W: eadem, Skubalanka, O stylu poetyckim i innych stylach języka. Studia i szkice teoretyczne (s. 68-71). Lublin: Wydawnictwo UMCS. [Pierwodruk: Skubalanka, T. (1973). Ekspresywność języka a mowa potoczna. W: S. Skwarczyńska (red.) (1973). Materiały Konferencji Komisji Poetyki i Stylistyki Słowiańskiej Międzynarodowego Komitetu Slawistów, Warszawa 18-20 kwietnia 1972, Poetyka i stylistyka stowiańska (s. 177-183), Wrocław: Zakład Narodowy im. Ossolińskich].

Styla, A. (1675). Grammatica Polono-Italica abo sposob łacny nauczenia się włoskiego języka krotko, gruntownie, choćby też i bez dyrekcyjej nauczyciela ku pożytkowi Narodu Polskiego z rożnych przedniejszych grammatykow z pilnościa wygotowany. Kraków. Pobrane z https://fbc.pionier.net. $\mathrm{pl} / \mathrm{search} \# \mathrm{fq}=\{$ !tag=dcterms_accessRights $\}$ dcterms_accessRights $\% 3 \mathrm{~A} \% 22 \mathrm{Dost} \% \mathrm{C} 4 \% 99 \mathrm{p} \% 20$ otwarty\%22\&q=id\%3Ann7r2b0 (12.08.2019).

Urbańczyk, S. (1993). Dwieście lat polskiego językoznawstwa (1751-1950). Kraków: Secesja.

Warchoł, S. (1974). Formacje ekspresywne a system języka. Biuletyn PTJ, XXXII, s. 71-85.

Wierzbicka, A. (1969). Problemy ekspresji. Ich miejsce w teorii semantycznej. W: eadem, Dociekania semantyczne (s. 33-61). Wrocław-Warszawa-Kraków: Zakład Narodowy im. Ossolińskich.

Wincewicz, K. (online). Adam Styla, Grammatica Polono-Italica abo sposob łacny nauczenia się wtoskiego języka krotko, gruntownie, choćby też i bez dyrekcyjej nauczyciela ku pożytkowi Narodu Polskiego z rożnych przedniejszych grammatykow z pilnościa wygotowany, Kraków 1675. Pobrane z https://gramatyki.uw.edu.pl/book/259 (12.08.2019).

Wiśniewska, H. (1994). Zapomniana polska gramatyka języka włoskiego Adama Styli (1675). W: M. Kucała, Z. Krążyńska (red.), Studia Historycznojęzykowe, I (s. 221-230), Kraków: Instytut Języka Polskiego PAN.

Wóycicki, K. (1917). Stylistyka i rytmika polska. Podręcznik dla szkoły i samouków. Warszawa: Druk Rubieszewskiego i Wrotnowskiego. Pobrane z https://fbc.pionier.net.pl/details/nnnsV3d (8.12.2019).

Zgółkowa, H. (1991). Leksyka ekspresywna jako wyróżnik potocznej odmiany współczesnej polszczyzny. W: S. Gajda, Z. Adamiszyn (red.), Język potoczny jako przedmiot badań językoznawczych (s. 45-52). Opole: Wyższa Szkoła Pedagogiczna.

\section{Slowniki}

SW - Karłowicz J., Kryński A., Niedźwiedzki W. (red.) (1900-1927), Słownik języka polskiego, T. 1-8. Warszawa, http://ebuw.uw.edu.pl/publication/254. 
SL - Linde S.B. (1807-1814). Słownik języka polskiego, T. 1-6. Warszawa. http://kpbc.umk.pl/publication/8173.

SXVI - Mayenowa M.R. i in. (red.) (1966-), Stownik polszczyzny XVI wieku, T. 1-. Wrocław.

USJP - Dubisz S. (red.) (2008) Uniwersalny stownik języka polskiego, T. 1-4. Warszawa.

\section{STRESZCZENIE}

Słowa kluczowe: język polski, ekspresywność języka, leksyka ekspresywna, typologia wyrazów ekspresywnych.

Celem artykułu jest próba opisu polskiej terminologii związanej z ekspresywnością języka i leksyką ekspresywną na podstawie wybranych publikacji o charakterze dydaktycznym (historycznych gramatyk i podręczników) oraz opracowań językoznawczych opublikowanych w ostatnim półwieczu. W artykule omówiono wybrane terminy, np. ekspresywność, ekspresja, znak ekspresywny, ekspresywizm, oraz typologie wyrazów ekspresywnych autorstwa Teresy Skubalanki, Stanisława Grabiasa, Haliny Zgółkowej oraz Artura Rejtera. Opracowanie ma charakter teoretyczny i jest przyczynkiem do dalszych badań nad zagadnieniami ekspresywności języka i ekspresywizmów w ujęciu historycznym.

\section{SUMMARY}

Prolegomena to terminology related to language expressiveness and expressive lexis in historical approach

Keywords: Polish language, language expressiveness, expressive lexis, typology of expressive words.

The main aim of this paper is an attempt to describe the Polish terminology related to language expressiveness and expressive lexis on base of selected didactic works (historical grammars and handbooks) and linguistic dissertation published in the last fifty years. Author of this article discussed selected terms, e.g. expressiveness, expression, expressive sign, expressive words and typologies of expressive words by Teresa Skubalanka, Stanisław Grabias, Halina Zgółkowa and Artur Rejter. It is a theoretical paper which can be a prolegomena to further research on question devoted to language expressiveness and expressive lexis in historical approach. 